\title{
398. SPECT/CT画像の統合による分解能の評価
}

\author{
Study of resolution on 3D SPECT/CT fusion image
}

\author{
東邦大学医学部附属大森病院 核医学検查室 ${ }^{1 ｝ \text { X線診断室 }{ }^{2)} \text { 放射線科 } 3 \text { ) }$

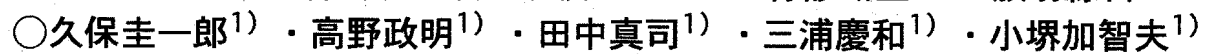 \\ 町田啓—2）・中野秀治 ${ }^{2)}$ ・津布久雅彦3)
}

【目的】SPECT画像における分解能の視覚的評価の容易な手段として、ホット\&コールドモジュー ルを用いた管理データが一般的である。今回我々は、ファントムを用いたSPECT画像およびCT画像を 統合することによりSPECT画像における分解能の限界を視覚的に評価するとともに、可視化ツールを 用いた三次元画像としての分解能を観察した。

【方法】低エネルギー用高分解能コリメータを装着した三検出器型SPECT装置（PRISM3000）に より ${ }^{99 \mathrm{~m}} \mathrm{Tc}-\mathrm{O}^{-4}(74 \mathrm{kBq} / \mathrm{ml})$ を注入した単光子放出体断層用ファントム (JIS 2-4922.typeL) を マトリクスサイズ128×128,6 $6^{\circ}$ step,60view,36sec/stepの収集条件にて行いSPECT画像を得た。 同ファントムを螺旋型CT装置（Xvigor）により $120 \mathrm{kV}, 200 \mathrm{~mA}$,スライス厚 $3 \mathrm{mmSlice} / \mathrm{secテーブ}$ ルスライドの収集条件にてCT画像を得た。両画像を可視化ツールソフトウエアAVS・MVにて画像統 合、三次元画像再構築を行いSPECT画像においてはVoxel解析を行った。SPECT画像とCT画像の統合 化をするにあたり、まずCT画像の輪郭表示したイメージにSPECT画像のX,Y,Z軸を移動、回転させ両 画像を統合した。統合画像上でSPECT画像のThresholdを30\%、40\%、50\%、60\%と変化させホット 、コールドモジュールの視覚的評価を行った。SPECT分解能三次元評価ではホットモジュールの画像 を用い各径にマスクをかけた画像より、Max Countを100\%とした容積とCountの分布曲線を作成し た。各グループの径 $1.9 \phi 、 1.6 \phi 、 1.3 \phi 、 1.0 \phi$ にスライス厚を乗じた真の容積を表わすThresholdと 各グループにおける容積の変動を認めた。

【結果】1）.同一ファントムによるSPECT画像とCT画像の三次元統合化を行うことができた。 [Fig.1]

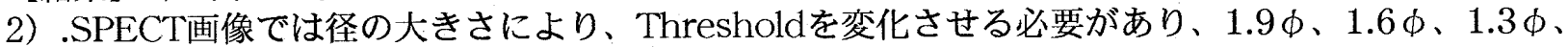
$1.0 \phi$ の順に $44 \% 、 49 \% 、 60 \% 、 73 \%$ Thresholdで実測值の容積に近い容積の画像が得られた。

3）.求められた各径のThresholdより得られた三次元画像とあるスライス面のSPECT画像を重稀せた 統合画像をFig.2に示す。

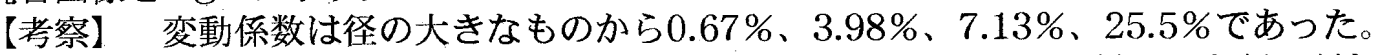
このことから、ホットモジュールにおけるVoxel解析では、大きさの異なった径に対し客観的な情報を 得ることができ、各領域でマスクをかけたVolume face 3D imageでは、径の小さいものほど、実測 值に反映するThresholdは高い值を示し、その変動径数は大きな値を示した。

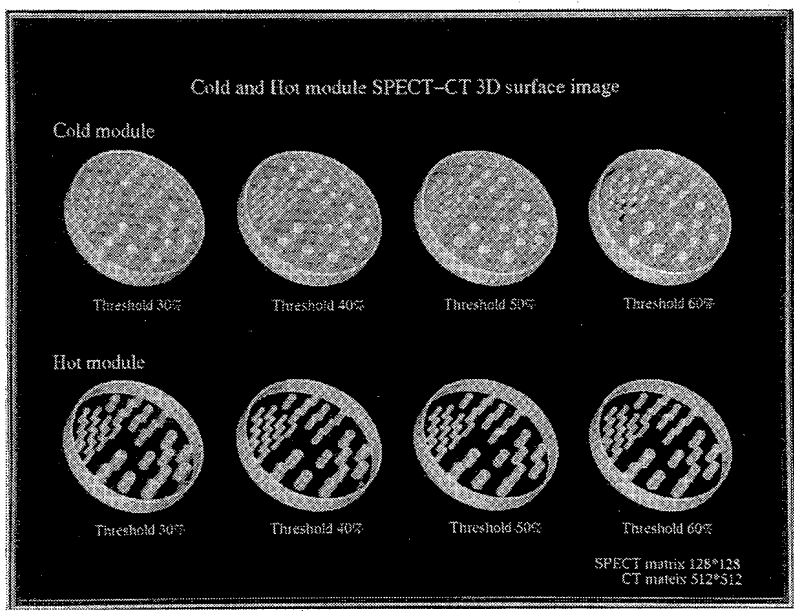

[Fig.1]

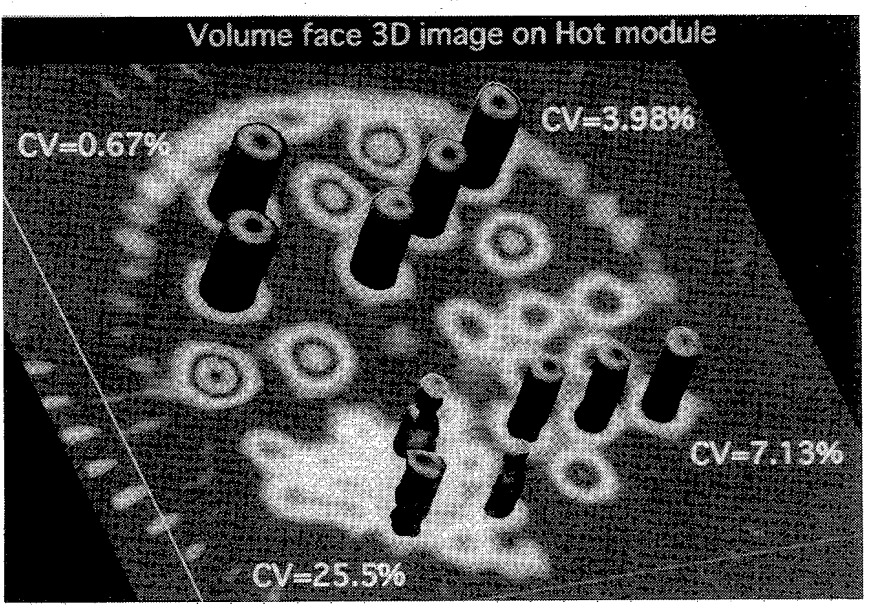

[Fig.2] 